\title{
Scriblerian Projections of Longitude: Arbuthnot, Swift, and the Agency of Satire in a Culture of Invention
}

\section{Gregory Lynall}

Devising a practical method to determine longitude at sea was the culturally predominant scientific and technical problem of the eighteenth century. Its solution had been raised as a direct concern of the state in other countries previously, but it became the focus of considerable British investment in July 1714, when the Longitude Act appointed Commissioners to judge all related projects and award up to $£ 2000$ to experimenters, and pay up to $£ 20000$ if a method gave a correct result to within half a degree of longitude, equivalent to 30 geographical miles. The precise reasons for establishing the British reward are still unknown, but the Act is claimed as "testimony of the utilitarianism of those active in the propagation of Newtonian natural philosophy" (Stewart, The Rise of Public Science 202). Its ramifications, however, were not only scientific, technological, and navigational, but also cultural; and it had human, as well as economic, costs.

Many "projectors" would soon respond to the reward, and almost immediately a group of intellectuals (including a renowned mathematician and Royal Society council member, and the Tories' chief ministerial writer) gathered in London to scrutinise the most prominent proposal. This was not the Board of Commissioners assembling at the Admiralty (they would not do so officially until 1737) (Dunn and Higgitt 82), but an alternative band of the brightest thinkers, including Jonathan Swift, Alexander Pope, John Gay, John Arbuthnot and Thomas Parnell. This unofficial club of satirists has become known as the "Scriblerians," after their collaborative Memoirs of Martinus Scriblerus (1741), a mock-biography of a foolish virtuoso and occasional projector, whose name would become a byword for intellectual vapidity and pedantry. Arguably, a "Scriblerian mode" of mock-learned satire was particularly developed by, and remains associated with this group, although they did not always write in this vein (see: Hammond 118; Marshall). In analysing these writings, scholars have traditionally characterised the Scriblerians as "Ancients" who poured scorn upon "Modern" learning of all kinds (see: Kerby-Miller; Levine). More recently, however, critics have challenged this view, acknowledging that the Scriblerian satires on science were often profoundly personal and political in their satirical motivations, and simultaneously revelled in the creative potency of new ideas associated with natural knowledge (see: Shuttleton; Lynall, Swift and Science). Continuing this approach, and in the context of new work in the history of science coinciding with the tercentenary of the Longitude Act, ${ }^{1}$ it is timely to re-assess Scriblerian responses to the longitude endeavour, especially in order to position them within early eighteenth-century cultures of satire and longitude-projecting more broadly, and not just in relation to the (albeit hugely prominent) Whiston-Ditton rocket scheme. In contrast to the AddisonSteele circle associated with Button's coffee-house, the Scriblerians have been viewed traditionally as at a distance, both socially and ideologically, from the networks of natural knowledge that facilitated the longitude endeavour (see: Nicolson and Rousseau; Worth). Looking closely at Scriblerian 'projections' of longitude within their wider context gives us a new appreciation of what these satirists (especially Arbuthnot and Swift) ${ }^{2}$ saw as the purpose and agency of their writings, reveals the close proximity of their satiric work to the expertise of the scientific community, and 
identifies how the personal and cultural resonances of longitude and other proposals inflected their parodies and satires.

In using the term 'projection', this article will evoke a number of its meanings: project or scheme (of course), but also; creative vision and transformation; the action of targeting something (particularly via satire), and; the formation of images or representations (including caricatures and parodies). To greater or lesser degrees, these meanings apply to both 'serious' and 'parodic' projects, emphasizing their mutual imaginative capacity and rhetorical power. It is also evident, but hitherto unexplored, that some 'genuine' proposals themselves adopted the use of comic and satiric modes in order to disparage other methods. Some of these satiric appropriations were inspired by the ironic posturing of The Longitudes Examin'd (1714), recently argued to be a hoax proposal (possibly by Arbuthnot) (Rogers, "The Longitude Impostor"), but others pre-dated this piece. Even John Harrison (1693-1776), whose timepieces would eventually bask in the glory of the reward, would be influenced by the Scriblerians when venting his frustrations with the Commissioners of his time.

\section{"Malicious Satyr" in Longitude Culture}

The immersion of the Scriblerians within the culture of natural knowledge is perhaps made most apparent when we survey the close links between these satirists and the original Longitude Commissioners, prominent members of the scientific and maritime establishment (although for brevity's sake not all of the connections will be listed here). Around 1707, Swift had been part of a coterie at Dublin Castle which included Thomas Herbert, Earl of Pembroke (c.1656-1733), the antiquarian, former First Lord of the Admiralty, and ex-President of the Royal Society. Swift was also acquainted with John Keill (1671-1721), Savilian Professor of Astronomy at Oxford, via their connections to Christ Church College (Lynall, Swift and Science 32-33, 59). Dr Arbuthnot FRS knew several of the Commissioners well, including Sir Isaac Newton (1643-1727), with whom he had served on a number of committees and boards over the years (Beattie 7-20). Appointed a "Visitor" to the Royal Observatory in 1710, Arbuthnot was instrumental in facilitating the (pirated) publication of Astronomer Royal John Flamsteed's (1646-1719) star catalogue Historia coelestis (1712), the ultimate goal of which was to produce a celestial map capable of determining longitude. ${ }^{3}$ Moreover, An Essay on the Usefulness of Mathematical Learning (1701), traditionally ascribed to Arbuthnot, argued that Edmond Halley's (1656-1742) two voyages across the Atlantic (1698-1700) would result in a theory of magnetic variation and a longitude method, ensuring national prosperity through increased global trade (Aitken 431). ${ }^{4}$ Given these personal links, it is not surprising that (as will become clear) the Scriblerians' satires never targeted the Board itself as an entity, but deferred to its expertise, and drew upon its authority.

As the Scriblerians banded together in 1714 to plot the exploits of Martinus, almost inevitably the longitude was not far from their minds, although it was bound up with other public affairs of the time, as parliament was pledging itself to other exorbitant pay-outs. Indeed, Swift joked to Arbuthnot that the government "had better Put out a Proclamation that whoever discovers the Pretender or the Longitude shall have 100000": the fee that had been set just a few weeks earlier, for the apprehension of the uncrowned James III (3 July 1714, in Woolley 1: 630). ${ }^{5}$ The significance of the state offering a financial incentive for scientific or technological innovation was evidently not lost on the Scriblerians, and like Henry Fielding after them, they joked about the Act's opportunity cost, with Martinus Scriblerus's friend Crambe wondering why "there was not a reward for such as could find out a fourth Figure in Logick, as 
well as for those who shou'd discover the Longitude" (Kerby-Miller 124; see: [Fielding] 23, and Fielding 11). Moreover, The Humble Petition of the Colliers (1716), which for satiric effect associates the Whiston-Ditton longitude solution with a project apparently seeking to monopolise the Sun's energy (Pettit 4: 72-78; see also: Lynall, "Bundling up the Sun-beams" 482-83), suggests that whilst the payment to a worthy solution might not have been an issue for the Scriblerians, they perhaps believed that the Act was giving encouragement to a deluge of poorly designed schemes from crack-pots claiming to be working for public benefit, whose botched (and fraudulent) projects might diminish public or private investment, and "bring People to run needless and unusual hazards" (as Daniel Defoe put it) (11). ${ }^{6}$

The passing of the Act was partly the result of lobbying by the former Lucasian Professor of Mathematics William Whiston (1667-1752), and his collaborator Humphrey Ditton (1675-1714), mathematical master at Christ's Hospital, London, who published their method on 14 July 1714, just days after the reward was established (Whiston and Ditton, A New Method for Discovering the Longitude). Joseph Addison, who along with Richard Steele and the "Buttonian" circle was a known supporter of (fellow Whig) Whiston's public lectures, said that the scheme "deserves a much higher Name than that of a Project, if our Language afforded any such Term" (Addison n.p.; see also: Nicolson and Rousseau 142-45, 167-68; Worth 355-59; Stewart, The Rise of Public Science 94-95). Meanwhile, Arbuthnot was less than complimentary, writing to Swift:

Whetstone has at last publish'd his project of the longitude the most ridiculous thing that ever was thought on, but a pox on him he has spoild one of my papers of scriblerus', which was a proposal for the longitude not very unlike his to this purpose, that since ther was no pole for East \& west that all the princes of Europe should joyn \& build two prodigious poles upon high mountains with a vast light house to serve for a pole Star. I was thinking of a calculation of the time charges \& dimensions. Now yow must understand his project is by light houses \& explosion of bombs, at a certain hour. (17 July 1714, in Woolley 2: 11-12)

Arbuthnot knew that Whiston and Ditton's project (despite making such a public fuss) was unworkable practically, not least because, as Flamsteed noted, the rockets "will be little or no use at sea both because of the short duration of the appearances and that the seamen will want to know where and at what Moment to look" ("Flamsteed to Abraham Sharp. 1 February 1714/15" in Forbes, Murdin and Willmoth 3: 723). Moreover, Newton observed that the method was "rather for keeping an Account of the Longitude at Sea, than for finding it, if at any time it should be lost" (Hall and Tilling 6: 161). Arbuthnot was aware too that another problem with this proposal was not only scientific and technological, but also political, requiring international cooperation for a fleet of stationary vessels to be maintained around the globe (a point emphasised via irony in the Memoirs of Scriblerus) (see: Kerby-Miller 168). Swift's reply to Arbuthnot offered artistic encouragement to a friend he recognised had a unique position in the group, as a published mathematician, Fellow of the Royal Society, and successful satirist: "It was a malicious Satyr of yours upon Whiston, that what you intended as a Ridicule, should be any way struck upon by him for a Reality. - Go on for the sake of Witt and Humor, and cultivate that Vein which no Man alive possesses but your self" (25 July 1714, in Woolley 2: 26; see also: "Swift to Arbuthnot. 3 July 1714" in Woolley 1: 630). 
The significance of this exchange has not been sufficiently appreciated. If his complaint at being beaten to the idea is taken at face value, it reveals that Arbuthnot was indulging in the vagaries of his projecting imagination to create an indiscriminate parody for comic purposes rather than seeking to achieve particular satire, drafting the piece in order to give vent to a flight of fancy that could satisfy his humorous, mathematical and inventive inclinations. Whilst the misspelling of Whiston's name is perhaps an intentional pun suggesting Arbuthnot's creative frustration at being outdone in practical absurdity by a serious proposal (a "whetstone" being used to sharpen blades, with the connotation of sharpening one's wit upon an embodiment of error), ${ }^{7}$ it does not seem to strike him that the similarity of his intellectual labours to those of Whiston and Ditton is something that can be exploited satirically. Swift, however, immediately recognises that Arbuthnot's idea could be framed as a fortuitous, proleptical parody of the bomb-vessel proposal (which was almost satirical in itself), and re-classifies the literary mode of the piece as a "malicious Satyr." Swift seemed unable to persuade Arbuthnot to continue with the intricate mathematical calculation he had initially envisaged: the light-house idea "to supply the defect of Nature, and to make the Longitude as easy to be calculated as the Latitude" would only re-surface in its abbreviated form, along with the "Bomb-Vessels" method, in a list of schemes censured merely via attribution to Martinus (Memoirs, 168, 167). ${ }^{8}$ However, a method involving signalling from systematically-positioned light-houses was genuinely proposed later that year (see: An Essay Towards a New Method To Shew the Longitude at Sea).

But perhaps Arbuthnot then conceived the greatest hoax of them all? Jeremy Thacker's The Longitudes Examin'd (1714) has been considered by some scholars to be a serious proposal for a timepiece at the "cutting edge of horological technology" in its conception and detail (Betts and King 6), and is credited with the first usage of the word "chronometer" (Thacker 23; see also: Andrewes 192; Glennie and Thrift 388-95). However, its ironic prefatory sections, which mock rival inventors and the economic incentive of the reward, led Pat Rogers to argue that the whole work, probably by Arbuthnot, is a spoof made to look like the real thing through its mockmathematics and accompanying diagrams (Rogers, "Satire as Mock-Science" 51). The resulting debate in TLS allowed Rogers to nuance his argument by conceding that the proposal may well contain passages of "innovative science," but that this does not preclude its being a hoax (Rogers, "Jeremy Thacker"). If Longitudes Examin'd was a Scriblerian spoof, there is no evidence any of its initial readers noticed. The scheme was certainly seen as genuine by John Ward, chief surveyor and gauger to the Excise, who also proposed a timepiece kept in a vacuum, and accused Thacker of plagiarising his idea (although William Derham had published accounts of experiments with pendulums in vacuo ten years' previously) (see: Ward, "The Preface"; Derham; Glennie and Thrift 391-92; Turner 124-26).

With its references to Keill and others, Longitudes Examin'd must have been written by someone immersed in the scientific community, and Arbuthnot was certainly as well-connected as they come. Arbuthnot also possessed the mathematical knowledge, but - if the piece is as accomplished as the historians of horology say whether he had the technical expertise to write the treatise on his own (without assistance from within the Royal Society or London clockmakers) is uncertain. ${ }^{9}$ It is therefore not inconceivable that the work was collaborative. Even so, it is difficult to imagine a natural philosopher or horologist allowing his genuine, innovative proposal to be compromised via its coupling with ironic passages mocking the mercenary culture established through the instigation of the reward. However, if Arbuthnot was 
the author, and on his own or in collaboration had embedded a legitimate method within a squib, this intention would certainly fit with his plan that the light-house idea would include a "calculation of the time charges \& dimensions."

Whether Longitudes Examin'd was serious or satiric, by Arbuth- [or] -not, this debate has yet to take into account that some proposals genuinely seeking the reward also incorporated ironic, comic and / or satiric prefatory passages which sought to deride other methods: more sparingly than in Longitudes Examin'd, but present nevertheless. For instance, the entrepreneur Case Billingsley, who himself proposed using a long-pendulum timekeeper, was sceptical about magnetism offering an answer, remarking that "we may with as much reason hope e're long to see the Heavens drawn with curious Black Meridians through every Tenth Degree of the Equator, which shall meet in the Poles, as to find a Stone that shall help us" (Billingsley 12-13). This ironic vision of a divinely-revealed solution shows how rhetorically useful it is to imagine a fantastical 'straw man' against which one can make a case for the credibility of one's own suggestion. Billingsley's method predates Thacker's: indeed, Thacker lampoons "Bill-y" (Thacker 3). So the author of Longitudes Examin'd was aware that irony was already part of the longitudeproposer's arsenal of rhetoric, and it was not a huge generic leap to twist the proposal form into a full-blown satiric critique of others' work. Where Longitudes Examin'd innovates is in its ironic posturing. The usual pose of serious proposals was to acknowledge one's humbleness before the gentlemanly Commissioners: Robert Browne and Francis Haldanby (both mentioned by Thacker) are notable examples of this politeness (Browne n.p. sig. A1 ${ }^{\mathrm{v}}$; Haldanby 2). The boastful Longitudes Examin'd therefore seeks to expose the faux humility of projectors through shamelessly emphasizing its own economic motivation and placing itself confrontationally amidst the proliferation of self-promoting texts.

Subsequent proposers were provoked to reply to Longitudes Examin'd in a suitably ironic fashion. John Ward, mentioned above, responds to Thacker proclaiming "the Secret that Nature had Confess'd to ME" by asserting "you'l find your Mistake, in presuming to be Natures only beloved Darling" (n.p. sig. A3 ${ }^{r}$ ). Similarly inspired by Thacker's boldness, another projector (James Clarke) brashly claims that his own suggestion will "cool those Mens Brains, whose Heads have run so much upon Wheels ever since the Commencement of a late Act of PARLIAMENT, and put them upon thinking of new Methods for getting the Twenty thousand Pounds" (5). Clarke's acknowledgement that the reward has cultivated a culture of mercenary madness and desperation perhaps extends to accepting (half-ironically) his own hotheadedness.

The competitive environment that the Longitude Act created, together with the reward's open remit, was seemingly ripe for irony, lampoon and caricature to be used as rhetorical devices against rival schemes. Meanwhile, Newton's exasperation with one unworkable method he had been sent resulted in his only known joke:

His Project for the Longitude is as impracticable as to make a perpetual motion like that of the heart but much more uniform or to observe the Sun's meridional altitude to a second or to deduce the Longitude from the complement of the Latitude, or to find that complement by burning brandy. ("Newton to - . [22 March 1715]", in Hall and Tilling 6: 211)

The projectors themselves, recognizing the distinctive power of wit and laughter over mere invective, placed fellow proposals under satiric scrutiny. Those involved were 
not normally from the scientific establishment with (gentlemanly) reputations to maintain, but entrepreneurs (of a middling, but aspirational sort) (see: Cummings and Stewart 239-40) prepared to engage in the cut and thrust of satiric print culture. Knowledge of this new context might muddy the waters even further with regard to determining the authorship of Longitudes Examin'd, but it emphasises that we cannot marginalise satire, nor dismiss lightly its efficacy, as a mode within the culture of longitude.

\section{Newton's F-t}

Returning more firmly to the Scriblerians, this section will place their satires on the Whiston-Ditton scheme (particularly the "Ode for Musick, on the Longitude") alongside the works of others, to highlight variation in the methods of, and reasons for, its satiric censure. These comparisons allow us to see that in many instances the Scriblerians' collective satires were moderate, considered acts of discrimination rather than reactionary diatribes.

The brilliantly excremental "Ode for Musick" (1728), however, was their most flippant response to Whiston and Ditton, and over the years has been variously attributed to Parnell, Gay, and Swift. This bombastic, overtly-ludicrous, mockoperatic ode (audaciously rhyming "Whiston" and "Ditton" with "bep-st on" and "besh-t on") (Pettit 3: 172) seems particularly appropriate for a sonic-based scheme Arbuthnot thought was the most ridiculous thing he had ever heard (on the ode's authorship see: Osborn, Rawson, "Parnell on Whiston"; Nicolson and Rousseau 17778). This lampoon, which Gay and Pope called ironically an "extraordinary copy of verses" ("Gay and Pope to John Caryll. April 1715" in Sherburn 1: 288; "Gay and Pope to Congreve. 7 April 1715" in Sherburn 1:290), finds the Scriblerians at their most playful, gives us some early evidence of their interest in music (especially as a satirically adaptable form, that would flourish in Gay's Beggar's Opera [1728]), and in its scatology perhaps captures the kind of school-boy humour that would have pervaded their homo-social gatherings. Behind this squib (and the other Scriblerian satires on Whiston), however, lay genuine intellectual and moral concerns about (what Pope called) his "wicked" anti-Trinitarian ideas: although Ditton had a good name for rhyming, his satiric worth was far less (he had not courted religious controversy, and died in October 1714) ("Pope to Henry Cromwell. 12 or 13 July 1707" in Sherburn 1: 26). ${ }^{10}$

The ode was not published for over a decade, but its circulation in manuscript seemed wide, and found an audience receptive to the Scriblerians' worries about "Whistonism" (see: Rawson, "Parnell on Whiston" 92). However, it was the Scriblerians' imitators who went much further in explicitly connecting Whiston's longitude ambitions to his controversial theology. These co-conspirators also highlighted the economic motivation, which (Longitudes Examin'd excepted) the Scriblerians refrain from censuring, despite Whiston and Ditton blatantly demanding a "considerable Reward" before they "disclose so important and beneficial a Secret" (Whiston and Ditton, "Letter to Mr. Ironside"). Will-with-a-Wisp (1714), an attack on Whiston as a "false Fire who shakes the very Foundations of the Christian Faith," and apparently written by "A Gentleman formerly of Queen's College, Oxon," argues that the project "look[s] as yet only like a Trick to get Money, [. . .] A Sum of ten or twenty thousand Pounds would do fine Things, fill his Coffers, or his primitive Library with Arian Books" (n.p. sig. A2 ${ }^{\mathrm{v}}$, 59). Again, unlike the Scriblerians' responses at this time, Will-with-a-Wisp is also suspicious of the utility of successfully determining longitude at sea: "we should find out the shortest Passage to the East 
Indies; in order to enrich our own native Country, by sending out our Money in Specie, and fetching Home Trinkets, Fanfarons, or worse Drugs in Exchange," while "All our Tars [...] would be steering their Course for Terra Australis incognita in Multitudes, and unerringly making the pacifick Ocean, to ransack the rich Mines thereabouts for hid Treasure" (60).

Whiston's heresy was sometimes suspected to have developed directly from his adoption of Newtonian metaphysics (indeed, Newton himself attracted suspicion from High Church quarters, especially after his death in 1727), ${ }^{11}$ and this connection with the longitude was also exploited satirically by Scriblerian imitators. For instance, Whistoneutes (1731), by "Simon Scriblerus," characterises Whiston as a sycophantic dunce who tacitly accepts Newton's heterodox ideas, and idolises anything else that comes out of him:

When this grand Sir Isaac let a F-t, was it not more than ordinary and common in your Nose and Ears; in the one more savoury, in the other more sonorous, than the like you ever, in all your Life-time, heard from the rest of his fellow Creatures? And, when you went sometime since on Ship-board to angle for the Longitude, why did not you borrow Sir Isaac's A-e? The Reports of which might have been far more serviceable to you in that Experiment, than the Ecchoes of the great Guns you made use of. (20)

Whilst the elegies of James Thomson and others had been celebrating the unprecedented, "amazing Mind" of Newton, sending his soul out to "mingle with his Stars," "Simon Scriblerus" drags him back down to earth via scatological satire (Thomson 6, 5; see also: Glover). This vulgar reduction highlights how Whiston and Ditton's proposal was a discernible source of mockery that could be used to target (by association) Whiston's other forms of 'innovation' (see also: [Welchman] 28). Another serious longitude proposer with satiric inclinations, "R. B." (probably Robert Burleigh, secretary to Admiral Sir Francis Wheeler), even makes this equation between technical and theological transgression (and gross self-promotion) explicit:

To impose so much upon the World, as to make People believe Longitude is to be Discover'd [...] by a Propagation of Sounds [...] without taking any Notice of their fixing Hulls at certain Distances in the Sea, they may as well persuade our Country-men, that White is Black, and Black's White: But never an Arrian in this Kingdom, shall seduce me to hold with him in so great an Error. (15)

For the Scriblerians (and their imitators and accomplices), Whiston was an open goal that galvanised their satiric enterprise, especially given that 1714 brought forth into print not only the bomb-vessel proposal, but also (as G. S. Rousseau points out) another of Whiston's millenarian theories of cometary apocalypse (329). Previous critics have underplayed, however, the fact that Whiston was not only a supreme satiric object, but also the source of considerable imaginative potency, because he brought together so many different kinds of 'innovation' in thought and activity. "Whistonism" was a vehicle as well as a target: an anchor-point from which they could not only measure a multiplicity of malpractice, but also secure their own whimsical fantasies. 'Whistonian' mock-catastrophe, for instance, often caused (or at least, heralded) by celestial phenomena, became an occasion for social satire (see: Gay, A True and Faithful Narrative, in Dearing and Beckwith II: 473; Lynall, Swift 
and Science 141-42). However, the sheer proliferation of satires on Whiston inevitably skewed attitudes to discovering the longitude, making it the province of fools, but dangerous ones at that.

Despite originating as throwaway productions for a small coterie, the Scriblerian satires lived on in the culture of longitude in manifold ways. ${ }^{12}$ What is little known, however, is that despite, or perhaps because of the crudeness of the "Ode," it had many admirers, including the composer Benjamin Cooke (1734-93), who indeed set the verses to music, for which he earned a "Noblemen and Gentlemen's Catch Club" prize medal in 1767 (Cooke 1-8). Moreover, in 1775 John Harrison directed the sentiments of the poem towards the current Commissioners (including Astronomer Royal Nevil Maskelyne), scathingly remarking that "Whiston was pissed on, and Ditton shit on, but surely these Men ought to be besmear'd or bespatter'd with both" (67n): once again, a "projector" took up the weapon of satire. It would have delighted the Scriblerians to know that their jeu d'esprit, signed "Da Capo" (a musical term for "repeat"), had such an afterlife, including its appropriation by the most prominent solver of the longitude problem.

\section{Jo's Throat}

Whilst the collaborative Scriblerian satires on longitude had focused on the antiTrinitarian Whiston, Swift had other (and more personal) reasons to be wary of the effects of the reward, which made an impression upon his greatest work. To put this later experience into context, however, we need to venture back to March 1712, when Swift was at the height of his influence in English political affairs, working for Robert Harley's administration as a propagandist, and writing to his close friend Esther Johnson (Stella):

A Projector has been applying himself to me to recommend him to th Ministry, because he pretends to have found out te Longitude. I believe $\mathrm{He}$ has no more found it out, than he has found mine a[---]. However I will gravely hear what he says, and discover him a Knave or Fool. (28 March 1712, in Swift 9: 418-19)

In a more polite letter on the topic written the next day, to Archbishop William King, Swift supplied further details (that the "Projector" had petitioned the Queen via Henry St John regarding his "Invention"), and confessed: "I understand nothing of the Mathematicks, but I am told it [a longitude solution] is a Thing as improbable as the Philosopher's Stone, or perpetual Motion" (29 March 1712, in Woolley 1: 421). ${ }^{13}$ Critics have long proposed that this "Projector" was none other than Whiston, but as Larry Stewart points out, there are plenty of other possible candidates (The Rise of Public Science 209). If the man was the notorious Whiston, it seems strange that Swift would not identify him by name. Certainly, just a few months later, Swift's $\mathrm{Mr}$. C$n s$ 's Discourse of Free-Thinking (1713) specifically targets Whiston for his controversial theology (Davis 4: 31).

Whatever the projector's identity, Swift's reactions are significant particularly because, in the letter to King, Swift mentions his own Proposal for Correcting, Improving and Ascertaining the English Tongue (1712). Swift recognises that his attempt to regulate the English language has a parallel with longitude solutions, noting, "Your Grace sees I am a Projector too" (Woolley 1: 421; see also: Davis 4: 20). This self-conscious acknowledgement of his own compulsion for projecting is present throughout his career: evident in his serious pamphlets about Irish economics, 
and in putting forward (at least ironically) that his satires are kinds of reformative project (see: Treadwell). The longitude as a conventional satiric trope for impossible enterprise was even used against Swift himself, with his intellectual enemy the Whig historian John Oldmixon scoffing that "The Doctor may as well set up a Society to find out the Grand Elixir, the Perpetual Motion, the Longitude, and other such Discoveries, as to fix out Language beyond their own Times" ([Oldmixon] 25).

Swift's use of "projector" highlights the word's multiple meanings. This polysemic term had been around for more than a century, and came to refer to many kinds of emerging scientific, financial and political professional (see: Ratcliff 34348). Whilst some of the literary conflations were partly borne out in reality (see: Stewart, The Rise of Public Science), it is utterly apparent that at various times Swift uses the pejorative connotations of the term (as private profiteer, even fraudster) for evocative purposes, as a kind of pre-loaded shorthand that could be easily deployed to achieve considerable satiric effect, often by associating one type of "projector" with another. Swift characterises the South Sea Bubble and William Wood's Irish halfpence, for instance, as the work of opportunistic "projectors," and connects both to kinds of economically-exploitative colonial and alchemical enterprise. In The Drapier's Letters, Swift's narrator even makes a direct link between the Longitude Act and the Crown's controversial payment to the coinage manufacturer and "PROJECTOR" Wood, asking: "Hath he discovered the Longitude, or the Universal Medicine? No; but he hath found out the Philosopher's Stone after a new Manner, by Debasing of Copper, and resolving to force it upon us for Gold" (Davis 10: 35-36). This analogy is particularly pertinent given the role played by Newton, as Master of the Mint, in endorsing Wood's copper currency: an action that incurred Swift's satiric wrath (Lynall, Swift and Science 94-119). The reputation of the longitude endeavour would therefore itself suffer through association with ludicrous or corrupt projects of other sorts in Swift's satiric imagination.

Swift also witnessed how the reward affected real lives. Appointed vicar of Laracor, County Meath, in 1700, Swift there became the friend and customer of Joseph Beaumont, a local linen draper and general merchant (see: Ehrenpreis 2: 9495, 365). Swift's go-to practical man, Beaumont was interested in mathematics and natural philosophy, and put his expertise to use: proposing improvements to Dublin harbour, and publishing geometrical tables for textile manufacture (Beaumont, $A$ Proposal; Beaumont, Mathematical Sleaing-Tables); and for the latter, through Swift's contacts, he secured a government reward of $£ 200$ in 1711 (see: Swift 9: 8, 11, $14,17,27,203,205,319,334,354)$. Buoyed by this success, Beaumont turned his attention to other schemes, principally longitude solutions, and this started possibly as early as 1712, when Swift writes to Johnson of a recent request: "Jo is a Fool; that sort of Business is not at all in my way: Pray put him off it. People laugh when I mention it" (8 March 1711-12, in Swift 9: 404; see also: 412) (this is within days of the anonymous "Projector" petitioning the Queen). Unfortunately, Beaumont seemed to become a real-life example of the 'longitude lunatic' frequently present in satirical trips to Bedlam (see: Bedlam 16-17; Lyttelton 14; Paulson 1: 169-70). By 1715, Beaumont was experiencing mental health problems, which some contemporaries attributed directly to his fixation with the longitude, with one mutual friend imploring Swift: "for God sake do somew[ha]t to comfort Jo: [. . . ] help him in his Longitude, do any thing to keepe him alive" ("Knightley Chetwode to Swift. 25 April 1715", in Woolley 2: 120; see also: Woolley 3: 141, 195, 220, 221, 222, 418, and Deane Swift 4: 2n). Not much is known about his treatment, recoveries and relapses, but in 1722 Beaumont was "mad in London riding thro the streets" and Swift tried to send him to 
Bedlam ("Swift to Rev. Daniel Jackson. 26 March 1722", in Woolley 2: 418). Unfortunately the Bedlam archive has no record of this affair. ${ }^{14}$ Beaumont returned to Ireland, and was still supplying Swift with goods in at least August 1725, but in December 1726 Swift received a "spleenatick Letter about poor Jo," and by 1727 he had committed suicide ("Swift to the Rev. John Worrall. 31 August 1725", in Woolley 2: 593; "Swift to [Robert Lindsay]. 8 December 1726", in Woolley 3: 64; Deane Swift 4: 2n).

Given this sad experience, it is not surprising that little help was forthcoming when another Irishman, John Wheldon, sought his advice in 1727 regarding a potential lunar-distance method he had already sent to prominent persons, including "Dr. Halley at Greenwich" (to no avail) ("Wheldon to Swift [Sept. 1727]." in Woolley 3: 239-40). Swift replied, offering sincere advice about the threat of plagiarism, acknowledging the Board of Longitude's role, and name-checking three of its members:

I understand not Mathematicks, but have been formerly troubled too much with Projectors of the Longitude to my great Mortification and some Charges by encouraging them. [. . .] Newton, Halley, and Keil have all told me they doubted the Thing was impossible. [. . .] there is, I hear, a course taken that you may discover it in London without being defrauded of your Invention. One of my Projectors cut his Throat, and the other was found an Imposter. This is all I can say; but am confident you would deceive others, or are deceived yourself. (27 Sept. 1727, in Woolley 3: 240; see also Davis 5: 206)

The letter confirms that Swift was interested enough in the longitude endeavour to consult with some of the Commissioners (or Commissioners-to-be), perhaps on behalf of Beaumont, or when approached by the anonymous "Projector" in 1712. Moreover, Swift's apophasis ("doubted the Thing was impossible"), and his suspicion of longitude projectors' motives, chance of success, and state of mind is indeed consistent with the opinions of Newton, Halley and Keill, who knew what the possible methods were, but saw it as extremely difficult to achieve practically with the astronomical techniques and / or technology available. In his published lectures, Keill laments that:

Many, tempted by so great a Reward, [. . .] much in Love with their own Inventions, [. . .] have demanded the Reward promised to the Discoverer; but yet most of these Men have been so ignorant that they have scarce known what it is to find the Longitude. (Keill 188-89)

Both Newton and Halley believed that a refinement of the lunar distance method was the most likely solution. Newton was particularly abrupt with those who considered otherwise, and in one letter-draft even entreated an un-named recipient to concern him no "further with Projectors": a sentiment Swift well understood (see: "Newton to - . [c. end of 1714]", and "Newton to - . [22 March 1715]", in Hall and Tilling 6: 197, 212n5; "Newton to Burchett. [October] 1721", and "Newton to the Admiralty. 26 August 1725", in Hall and Tilling 7: 172, 330; MacPike 212, 238).

We can assume that the "Imposter" Swift refers to is the same person he met in 1712, and the suicide is Beaumont, but the nature of Swift's "encourag[ement]" of the "Projectors" is uncertain. Supplementary to payments for goods, Swift gave Beaumont around $£ 6$ per year for an unknown reason. In addition, Beaumont owed 
$£ 100$ (for which Swift had a mortgage on Beaumont's house in Trim), and $£ 60$ (for which Swift had arranged securities with Bishop Stearne of Clogher) (Thompson and Thompson, 316). Perhaps Swift saw Beaumont's money troubles, and consequently his own expensive donations, as a direct result of the longitude obsession and resultant madness? Nevertheless, the letter to Wheldon confirms Swift suspected that "Projectors" could be a problem both to society and to themselves: a belief played out in the narrative of the "Voyage to Laputa," Book III of Gulliver's Travels (1726).

As I have argued elsewhere, Beaumont's psychological characteristics seem to be reflected in the introspected and anxious Laputians, who each require a bash to the head to wake them up from their "intense Speculations" in mathematics (Lynall, Swift and Science 92-93). However, the figure of Beaumont should also inform our readings of the Academy of Lagado, where a legion of projectors are at work on harebrained schemes. Previous scholarship on Swift and projecting has never mentioned Beaumont, perhaps because there is no longitude projector at work in the Academy, nor any other direct allusion in the Travels to Beaumont's predicament. However, it has been noted recently that the Academy is reminiscent of not only Crane Court, then home of the Royal Society, but also Bethlehem Hospital (see: Rivero 151n6). Gulliver's tour of the facility at times does seem more like an inspection of Bedlam's inmates, some of whom are quite literally doing brown "Vessel" (261) rather than 'blue sky' research. Projects are inevitably products of creative vision, which in parodic form can be twisted to border on wild fantasy and insanity. Indeed, when Swift was at work on the Travels, Arbuthnot connected scientific creativity with mental illness by offering to acquaint him " $\mathrm{w}^{\mathrm{t}}$ some new improvements [. . .] Mankind has an inexhaustible source of invention in the way of folly, \& madness" ("Arbuthnot to Swift. 17 October 1725", in Woolley 3: 615), whilst Swift's own A Tale of a Tub (1704) associated "great Introducers of new Schemes in Philosophy" with the "Academy of Modern Bedlam" (Swift 1: 107-08). The misdirection of talent in the Academy therefore evokes tragi-comic potential: there is something desperately sad about some of the projectors Gulliver meets, who are "driven equally on by Hope and Despair" (257), hinting at Beaumont's coexistent struggles with devising a longitude solution and living with mental illness. Moreover, there are some telling comments about the projectors' "Practice of begging from all," with Gulliver appeasing the cucumber experimenter's madness with coins Lord Munodi had "furnished" him with for that very purpose (260). As we have seen, Swift admitted longitude projectors had cost him "some Charges," perhaps almost as much as $£ 160$ in bailing out Beaumont at times of crisis.

Correspondingly, although the possible targets of the Lagadan projects have been documented by critics (some identifying Royal Society experiments, others the commercial schemes of Exchange Alley) (for the Royal Society see: Nicolson and Mohler; for Exchange Alley see: Case 89-91; Rogers, "Gulliver and the Engineers"), a case can be made for a more comic (and perhaps sympathetic) than satiric tone in relation to some of the individual fictional projects: with the corollary that Swift was inspired by, but not necessarily always disparaging, some of the specific experiments and inventions he burlesques. There is, however, a more serious argument made about state encouragement of innovation, and the inability of projectors to live up to their utilitarian claims: while the Academy incubates an array of 'improvements' which are at best impractical, and at worst medically or environmentally irresponsible, outside its walls the citizens of Balnibarbi are generally poverty-stricken, financially-exploited and politically-subordinated. $£ 20,000$ would not go far in alleviating the ills afflicting a whole population, but something is better than nothing. 
Although the problem of reliable navigation at sea was preoccupying many minds, including some close to Swift, it was perhaps creatively advantageous to him for a credible longitude solution to lie undiscovered. Swift's geographical imagination had made the most of navigational and cartographical inaccuracy, projecting fictional lands onto uncharted spaces (almost like an explorer-entrepreneur promising a share of Terra Australis Incognita). If the indeterminate areas around Australasia and the Pacific had been adequately measured and mapped, then the Travels might have been a very different work (for a graphic illustration, see: Case, $54 \mathrm{ff}$.). In the story itself, Gulliver is perennially lost at sea, and is understandably frustrated with orientational imprecision. But when banished from the land of the Houyhnhnms in a canoe made from Yahoo skins, and without any instruments, Gulliver is still somehow able to calculate that the "Maps and Charts place [New-Holland] at least three Degrees more to the East than it really is; which Thought I communicated [. . .] to my worthy Friend, Mr. Herman Moll" (Swift 16: 427-28; on Herman Moll's A New \& Correct Map of the Whole World (1719) as a source for the Travels see also: Bracher, and Case 50-53). This navigational correction of the most popular contemporary mapmaker forms part of the narrative's mock-impulse for authenticity.

It is inevitable that when the habitually-marooned Gulliver hears about the immortal Struldbruggs, and contemplates what eternal life would be like, he thrillingly imagines seeing "the Discovery of the Longitude, [. . .] and many other great Inventions brought to the utmost Perfection" (314). Unlike his narrator Gulliver, Swift himself may have been suspicious about the advantages of a fully-mapped, navigable world. His writings on Irish economics suggest that he was doubtful that increased international trade brought national prosperity, unless the country happened to be the head of an empire (see: Davis 12:12). Moreover, at the end of the Travels is a crushing indictment of colonialism. Gulliver, at this point in a voice indistinguishable from Swift's own, describes that when a new land is discovered, "Ships are sent out at the first Opportunity; the Natives driven out or destroyed, their Princes tortured to discover their Gold; a free Licence given to all Acts of Inhumanity and Lust; the Earth reeking with the Blood of its Inhabitants" (441) (on this passage as part of a long anti-colonial tradition, see: Rawson, God, Gulliver, and Genocide 1724). In his more misanthropic moments, Swift may have wondered (like the author of Will-with-a-Wisp) whether the principal effect of a longitude solution would be to increase the efficiency of such cruelty.

The liminal position of the Scriblerians within the networks of natural knowledge meant that from a unique vantage point their writings reflected and shaped intellectual, moral and cultural questions associated with the longitude and other projects, particularly concerning the validation and commodification of technological improvement. The satiric trajectories of their works often had an authoritative basis in the expertise of the scientific community, yet these were also modulated according to the Scriblerians' own experiences and prejudices, and could even elicit some sympathy for the plight of the despondent projector. The cultural prominence of longitude proposals also gave the Scriblerians license to pursue their own projecting imaginations, inhabiting the project-genre parodically for satiric, but also whimsical purposes. The longitude projectors, moreover, also recognised the value of ludic discourse and rhetorical trickery in refuting the credibility of competing schemes. In a number of ways, therefore, the satiric mode made a distinctive, and at times decisive, contribution to the longitude endeavour (and, ultimately, to debates about the agency and authority of natural knowledge), despite the Scriblerians' suspicion of any attempts to measure, control or mend the world. 


\section{Notes}

1. Department of History and Philosophy of Science, University of Cambridge, and National Maritime Museum, Greenwich, "The Board of Longitude 1714-1828: Science, innovation and empire in the Georgian world" project. I was honoured to speak at the "Longitudes Examined" Tercentenary Conference (Greenwich, July 2014) and developed my paper into this article. I am especially grateful to Simon Schaffer, Katy Barrett and Paul Baines for their suggestions and encouragement.

2. Pope, Gay and Parnell say little about the longitude outside the collaborative satires.

3. See Royal Society MSS. 2: 229-32 (14 December 1710), and the exchange between Arbuthnot and Flamsteed, and Arbuthnot and Newton, in Ross 128-40, 145, 147-48. Given this involvement, it is no wonder that the Memoirs emphasises the extent to which navigation was at the forefront of the practical application of natural knowledge (168). See also Gay, "The Pin and the Needle," 41-44, in Dearing and Beckwith 2: 322-23.

4. The BL copy of An Essay on the Usefulness of Mathematical Learning (1701) [618.c.28] is ascribed to Arbuthnot by a contemporary hand. Halley suggested Arbuthnot as his replacement as Clerk to the Royal Society whilst on one of the voyages, but this request was refused (Cook 271).

5. See also Swift's The Publick Spirit of the Whigs (1714), which refers to the political machinations behind the Pretender's exile from France to the neighbouring duchy of Lorraine: "I thought indeed we should be Safe from all Popish Successors as far as Italy, because of the prodigious Clutter about sending the Pretender thither. But they will never agree where to fix their Longitude" (Swift 8: 279).

6. The Humble Petition was re-published in the Pope-Swift Miscellanies. Aitken (88), Beattie (303), Kerby-Miller (339), and Teerink and Scouten (440) all ascribe its authorship to Arbuthnot, and "by $\mathrm{D}^{\mathrm{r}}$ Arbuthnot" is handwritten on the British Library copy (816.m.19). On the satiric targets of the work, see: Rousseau 333, Viner 99, Steensma 42, and Nicolson and Rousseau 175-76.

7. Cf. Swift, A Modest Defence of Punning (c. 1716), in Swift 2: 165, and see: n31.

8. The Scriblerians' next virtuoso was the unenlightened Dr. Fossile, who when asked about the longitude problem remarked, "I deal not in impossibilities. I search only for the grand Elixir": Three Hours After Marriage (1717), II, 262, in Fuller 1: 237.

9. One (not insurmountable) reservation about ascribing Longitudes Examin'd to Arbuthnot: Thacker argues that an astronomical answer to the longitude problem will only be possible if "the great Mr. L-, with an Industry equal to his Candour, should join the Fluxions and Series, which he invented, to his known Skill in the Laws of Centripetal and Centrifugal Forces" (8). The passage is probably ironic, but it is hard to believe that Arbuthnot, who knew Newton well, and served on the Royal Society committee concerned with the priority of calculus' discovery, would wish to make this brazen attribution even ironically via his putative author Thacker: it seems too close to the bone, and was too likely to be taken seriously. On Arbuthnot and calculus, see Beattie 7-20.

10. Pope, however, would be inspired by Whiston's astronomy, and attended his coffee-house talks. See "Pope to John Caryll. 14 August 1713" in Sherburn 1: 185; Nicolson and Rousseau 137-49; Force 165n77. The satires on Whiston include: God's 
Revenge Against Punning (1716), The Humble Petition of the Colliers (1716), (arguably) parts of Gulliver's Travels (1726), and A True and Faithful Narrative of What Passed in London (1732). See Pettit 4: 53-56, 72-78; Swift 16: 236; Dearing and Beckwith 2: 464-73. For discussion of these works, see especially: Nicolson and Rousseau 174-87, Rousseau 325-41, Leonard, and Peterson.

11. See especially: Stewart, "The Trouble with Newton" 224. By the time of the Longitude Act, Newton had fallen out with Whiston, and probably would have endorsed the Scriblerians' satires.

12. See, for instance: Prior, Alma (1718), Canto III, 11. 368-69, in Prior 1: 50910; Hogarth, The Rake's Progress (1735), Plate 8, in Paulson 1: 169-70; Smollett, The Life and Adventures of Sir Launcelot Greaves (1760-1) 186.

13. Conflating the longitude problem with those other standard chimeras, Swift adopts the charges long used in relation to alchemists: see, for instance, his former employer William Temple's "Some Thoughts upon Reviewing the Essay of Ancient and Modern Learning", in Temple 87.

14. Swift was elected a governor on 26 February 1713/4. See Bridewell and Bethlem. I am much obliged to Colin Gale, Bethlem Hospital Archive, for searching the committee and admission notebooks on my behalf. 


\section{Works Cited}

Addison, Joseph. The Guardian, 107 (11 July 1713).

Aitken, George A., ed. The Life and Works of John Arbuthnot. Oxford: Clarendon Press, 1892.

Andrewes, William J. H. "Even Newton Could Be Wrong: The Story of Harrison's First Three Sea Clocks." The Quest for Longitude. Ed. Andrewes. Cambridge, MA: Harvard UP, 1996. 190-234.

An Act for providing a Publick Reward for such Person or Persons as shall Discover the Longitude at Sea. London: John Baskett, 1714.

An Essay Towards a New Method To Shew the Longitude at Sea; Especially near the Dangerous Shores. London: E. Place, 1714.

Beaumont, Joseph. Mathematical Sleaing-Tables: Or, The Great and only Mistery of Weaving Linnen-Cloth Explain'd. Dublin: A Rhames, 1712.

---. A Proposal for the More Effectual Improvement of the Channel and Harbour of Dublin. Dublin?, 1710?.

Beattie, Lester M. John Arbuthnot: Mathematician and Satirist. Cambridge, MA: Harvard UP, 1935.

Bedlam: A Poem. London, 1726.

Betts, Jonathan and Andrew King. "Jeremy Thacker: Longitude impostor?" Times Literary Supplement Issue 5529 (20 March 2009): 6.

Billingsley, Case. The Longitude at Sea, Not to be found by Firing Guns, nor by the Most Curious Spring-Clocks or Watches. London: Richard Mount and John Morphew, 1714.

Bracher, Frederick. "The Maps in Gulliver's Travels." Huntington Library Quarterly 8 (1944-45): 59-74.

Bridewell and Bethlem, Minute Books of the Court of Governors, 1713-22, Bethlem Royal Hospital Archives, MS. BCB-19 (Box C04/3), LL ref: BBBRMG202040074. London Lives. Web. 01 Dec. 2014.

Browne, Robert. Methods, Propositions and Problems, for Finding the Latitude; With the Degree and Minute of the Equator upon the Meridian. And The Longitude at Sea. London: R. Hookey and J. Harrison, 1714.

Case, Arthur E. Four Essays on "Gulliver's Travels." Gloucester, MA: Peter Smith, 1958.

Clarke, James. The Mercurial Thermometer Improv'd. London: J. Morphew, 1715.

Cook, Alan. Edmond Halley: Charting the Heavens and the Seas. Oxford: Clarendon Press, 1998.

Cooke, Benjamin. "The Longitude mist on." A Sixth Collection of Catches, Canons and Glees for three, four and five Voices. Ed. Thomas Warren. London, [1767]. 1-8.

Cummings, A. J. G., and Larry Stewart. "The Case of the Eighteenth-Century Projector: Entrepreneurs, Engineers, and Legitimacy at the Hanoverian Court in Britain." Patronage and Institutions: Science, Technology, and Medicine at the European Court, 1500-1750. Ed. Bruce T. Moran. Woodbridge: Boydell Press, 1991. 235-61.

Davis, Herbert, et al, eds. The Prose Works of Jonathan Swift. 14 vols. Oxford: Blackwell, 1939-68.

Dearing, Vinton A., and Charles E. Beckwith, eds. Poetry and Prose of John Gay. 2 vols. Oxford: Clarendon Press, 1974. 
Defoe, Daniel. An Essay upon Projects. 1697. Eds. Joyce D. Kennedy, Michael Seidel and Maximillian E. Novak. New York: AMS Press, 1999.

Derham, William. "Experiments about the Motion of Pendulums in Vacuo." Philosophical Transactions 24: 294 (1704): 1785-9.

Dunn, Richard, and Rebekah Higgitt. Ships, Clocks \& Stars: The Quest for Longitude. Glasgow: Collins, 2014.

Ehrenpreis, Irvin. Swift: The Man, His Works, and the Age. 3 vols. London: Methuen, 1962-83.

[Fielding, Henry]. An Attempt towards a Natural History of the Hanover Rat. London, 1744.

Fielding, Henry. A Proposal for Making an effectual Provision for the Poor. Dublin: John Smith and Richard James, 1753.

Forbes, Eric G., Lesley Murdin and Frances Willmoth, eds. The Correspondence of John Flamsteed, the First Astronomer Royal. 3 vols. Bristol: Institute of Physics, 1995-2002.

Force, James E. William Whiston: Honest Newtonian. Cambridge: Cambridge UP, 1985.

Fuller, John. John Gay: Dramatic Works. 2 vols. Oxford: Clarendon Press, 1983.

[A Gentleman formerly of Queen's College, Oxon]. Will-with-a-Wisp; Or, The Grand Ignis Fatuus of London. London: J. Woodward, A Bettesworth, E. Curll and R. Gising: 1714.

Gingerich, Owen. "Cranks and Opportunists: 'Nutty' Solutions to the Longitude Problem." The Quest for Longitude. 134-48.

Glennie, Paul, and Nigel Thrift. Shaping the Day: A History of Timekeeping in England and Wales 1300-1800. Oxford: Oxford UP, 2009.

Glover, Richard. "A Poem on Sir Isaac Newton." Henry Pemberton. A View of Sir Isaac Newton's Philosophy. London, 1728. n.p. sig. A6 ${ }^{\mathrm{r}}-\mathrm{C} 2{ }^{\mathrm{r}}$.

Haldanby, Francis. An Attempt to Discover the Longitude at Sea. London: John Morphew, 1714.

Hall, A. Rupert, and Laura Tilling, eds. The Correspondence of Isaac Newton, 7 vols. Cambridge: Cambridge UP for the Royal Society, 1959-77.

Hammond, Brean. "Scriblerian Self-Fashioning." Yearbook of English Studies 18 (1988): 108-22.

Harrison, John. A Description Concerning Such Mechanism as will afford a Nice, or True Mensuration of Time. London: T. Jones, 1775.

Keill, John. An Introduction to the True Astronomy: or, Astronomical Lectures, Read in the Astronomical School of the University of Oxford. London: Bernard Lintot, 1721.

Kerby-Miller, Charles, ed. The Memoirs of the Extraordinary Life, Works, and Discoveries of Martinus Scriblerus. New Haven, CT: Yale UP, 1950.

Leonard, David Charles. "Swift, Whiston, and the Comet." English Language Notes 16 (1979): 284-7.

Levine, Joseph M. Dr. Woodward's Shield: History, Science, and Satire in Augustan England. Berkeley: U of California P, 1977.

Lynall, Gregory. “'Bundling up the Sun-beams': Burning Mirrors in EighteenthCentury Knowledge and Culture." Journal for Eighteenth-Century Studies 36 (2013): 477-90.

---. Swift and Science: The Satire, Politics, and Theology of Natural Knowledge, 1690-1730. Basingstoke: Palgrave Macmillan, 2012. 
Lyttelton, George Lord. Letters from a Persian in England, to his Friend at Ispahan, 2nd ed. London: J. Millan, 1735.

MacPike, Eugene Fairfield, ed. Correspondence and Papers of Edmond Halley. Oxford: Oxford UP, 1932.

Marshall, Ashley, "The Myth of Scriblerus." Journal for Eighteenth-Century Studies 31 (2008): 77-99.

Nicolson, Marjorie, and Nora M. Mohler. "The Scientific Background of Swift's Voyage to Laputa." Annals of Science 2 (1937): 299-334.

Nicolson, Marjorie Hope, and G. S. Rousseau. "This Long Disease, My Life": Alexander Pope and the Sciences. Princeton: Princeton UP, 1968.

[Oldmixon, John]. Reflections on Dr. Swift's Letter to the Earl of Oxford, About the English Tongue. London, 1712.

Osborn, James M. “"That on Whiston' by John Gay.” PBSA 56 (1962): 73-78.

Paulson, Ronald, ed. Hogarth's Graphic Works: First Complete Edition, rev. ed. 2 vols. London: Yale UP, 1970.

Peterson, Leland D. "Jonathan Swift and a Prose 'Day of Judgment'." Modern Philology 81 (1984): 401-6.

Pettit, Alexander, ed. Miscellanies in Prose and Verse by Pope, Swift and Gay (172732), 4 vols. London: Pickering \& Chatto, 2002.

Prior, Matthew. The Literary Works of Matthew Prior. Eds. H. Bunker Wright and Monroe K. Spears, 2 vols. Oxford: Clarendon Press, 1959; 2nd ed. 1971.

Ratcliff, Jessica. "Art to Cheat the Common-Weale: Inventors, Projectors, and Patentees in English Satire, ca. 1630-70." Technology in Culture 53 (2012): 337-65.

Rawson, C. J. God, Gulliver, and Genocide: Barbarism and the European Imagination, 1492-1945. New York: Oxford UP, 2001.

---. "Parnell on Whiston." PBSA 57 (1963): 91-92.

R. B. Longitude To be found out with A new Invented Instrument, both by Sea and Land. London: F. Burleigh, 1714.

Rogers, Pat. "Gulliver and the Engineers." Modern Language Review 70 (1975): 26070.

---. “Jeremy Thacker: Longitude fake?" Times Literary Supplement Issue 5531 (3 April 2009): 6.

---. Documenting Eighteenth Century Satire: Pope, Swift, Gay, and Arbuthnot in Historical Context. Cambridge: Cambridge Scholars Publishing, 2012. 45-62.

Ross, Angus, ed. The Correspondence of Dr. John Arbuthnot. München: Fink, 2006.

Rousseau, G. S. "Wicked Whiston and the English wits." Enlightenment Borders: Pre- and Post-Modern Discourses: Medical, Scientific. Manchester: Manchester UP, 1991. 325-41.

Royal Society MSS., Council Minutes (Copy), vol. 2 (1682-1727).

Scriblerus, Simon. Whistoneutes: or, Remarks on Mr. Whiston's Historical Memoirs of the Life of Dr. Samuel Clarke, \&c. London: T. Warner, 1731.

Sherburn, George, ed. The Correspondence of Alexander Pope, 5 vols. Oxford: Clarendon Press, 1956.

Shuttleton, David E. “'A Modest Examination': John Arbuthnot and the Scottish Newtonians." British Journal for Eighteenth-Century Studies 18 (1995): 4762.

Smollett, Tobias. The Life and Adventures of Sir Launcelot Greaves. 1760-1. Ed. David Evans. London: Oxford UP, 1973.

Steensma, Robert C. Dr. John Arbuthnot. Boston: Hall, 1979. 
Stewart, Larry. The Rise of Public Science: Rhetoric, Technology, and Natural Philosophy in Newtonian Britain, 1660-1750. Cambridge: Cambridge UP, 1992.

---. "The Trouble with Newton in the Eighteenth Century." Newton and Newtonianism: New Studies. Eds. James E. Force and Sarah Hutton. Dordrecht: Kluwer Academic, 2004. 221-37.

Swift, Deane, ed. Letters, Written by the Late Jonathan Swift, D.D., 6 vols. London, 1768.

Swift, Jonathan. The Cambridge Edition of the Works of Jonathan Swift. Ed. Claude Rawson et al. 17 vols. Cambridge: Cambridge UP, 2008-.

---. Gulliver's Travels. 1726. Ed. Albert J. Rivero. New York: Norton, 2002.

Teerink, Herman, and Arthur H. Scouten, eds. A Bibliography of the Writings of Jonathan Swift, 2nd ed. rev. and corrected. Philadelphia: U of Pennsylvania P, 1963.

Temple, William. Five Miscellaneous Essays by Sir William Temple. Ed. Samuel Holt Monk. Ann Arbor, MI: The U of Michigan P, 1963.

Thacker, Jeremy. The Longitudes Examin'd. London: J. Roberts, 1714.

Thomson, James. A Poem Sacred to the Memory of Sir Isaac Newton (1727), 3rd ed. London: J. Millan, 1727.

Thompson, Paul V., and Dorothy Jay Thompson, eds. The Account Books of Jonathan Swift. Newark: U of Delaware P, 1984.

Treadwell, J. M. "Jonathan Swift: The Satirist as Projector." Texas Studies in Literature and Language 17 (1975): 439-60.

Turner, A. J. "In the Wake of the Act, but Mainly Before." The Quest for Longitude. 116-32.

Viner, Jacob. "Satire and Economics in the Augustan Age of Satire." The Augustan Milieu: Essays presented to Louis A. Landa. Eds. Henry K. Miller, Eric Rothstein and George S. Rousseau. Oxford: Clarendon P, 1970. 77-101.

Ward, John. A Practical Method to Discover the Longitude at Sea by a new contrived Automaton. London, 1715.

[Welchman, Edward]. A Conference with an Arian, Occasion'd by Mr. Whiston's Reply to the Right Honourable The Earl of Nottingham. London: L. Lichfield, A. Piesley, W. Meadows and T. Combes, 1721.

Whiston, William, and Humphry Ditton. "Letter to Mr. Ironside." The Englishman (7 December 1713).

---. A New Method for Discovering the Longitude both at Sea and Land. London: John Phillips, 1714.

Woolley, David, ed. The Correspondence of Jonathan Swift, D. D., 4 vols. Frankfurt am Main: Lang, 1999-2007.

Worth, Chris. "Swift's 'Flying Island': Buttons and Bomb-Vessels." Review of English Studies n.s. 42 (1996): 343-60. 